EVALUASI, 3(1), Maret 2019, ISSN 2580-3387 (print) |ISSN 2615-2886 (online)

Homepage : http://e-journal.staima-alhikam.ac.id/index.php/evaluasi

DOI : : http://doi.org/10.32478/evaluasi.v3i1.201

Article type : Original Research Article

\title{
PENGARUH GAYA KEPEMIMPINAN KEPALA MADRASAH TERHADAP KINERJA PENDIDIDIK DAN KEPENDIDIKAN DI MADRASAH IBTIDAIYAH (MI) AL HUDA MAGUWO, SLEMAN.
}

\author{
Noorrela Ariyunita \\ Mahasiswa Program Magister PAI, UIN Sunan Kalijaga Yogyakarta
}

\begin{abstract}
This research is a type of field research analizing by taking the background of MI Al Huda, Maguwo, Sleman as a place ofthe research. The subjects of this study are principals, teachers, and students of MI Al Huda, Maguwo, Sleman. The object of this research is the educational leadership influence of the madrasa principals on the performance of educators and educational personnel. Data collection is done by conducting observations, interviews, and documentation. This research uses a phenomenological approach. The results of this research indicate the influence of the principal leadership on the performance of educators and educational personnel in MI Al Huda, Maguwo, Sleman, DIY. Conclusion of this research are (1) The principal always prioritizes deliberation and respect the opinions of subordinates before making decisions or policies in Madrasa. (2) The principal of the Madrasah gives freedom to educators and educational personnel to be creative and innovative in carrying out their duties. (3) The principal always tries to be a father figure for students by trying to be close and familiar with students. (4) The principal always controls every activity. (5) The principal always involves all school members and the local community to reach school goals.
\end{abstract}

Keyword: leadership, madrasa leadership style, educators, educational personnels

Email address: noorrelaa@gmail.com

EVALUASI: Jurnal Manajemen Pendidikan is licensed under

The CC BY License (https://creativecommons.org/licenses/by-sa/4.0/) 
EVALUASI, 3(1), Maret 2019, ISSN 2580-3387 (print) |ISSN 2615-2886 (online)

http://doi.org/10.32478/evaluasi.v3i1.201

\section{Abstrak}

Penelitian ini adalah jenis penelitian lapangan atau field research (penelitian lapangan) dengan dengan mengambil latar MI Al Huda, Maguwo, Sleman sebagai tempat penelitian. Subyek penelitian ini adalah kepala sekolah, guru, dan siswa MI Al Huda, Maguwo, Sleman. Sedangkan obyek penelitiannya adalah pengaruh kepemimpinan pendidikan kepala madrasah terhadap kinerja pendidik dan tenaga kependidikan. Pengumpulan data dilakukan dengan mengadakan observasi, wawancara, dan dokumentasi. Penelitian ini menggunakan pendekatan fenomenologis. Hasil penelitian ini menunjukkan adanya pengaruh kepemimpinan kepala madrasah terhadap kinerja pendidik dan tenaga kependidikan di MI Al Huda, Maguwo, Sleman, DIY. Dibuktikan dengan Pertama, selalu mengedepankan musyawarah dan memperhatikan pendapat bawahannya sebelum mengambil keputusan maupun kebijakan dalam Madrasah. Kedua, Kepala Madrasah memberikan kebebasan terhadap guru maupun karyawan untuk berkreasi dan berinovasi dalam melaksanakan tugasnya. Ketiga, selalu berusaha menjadi figur ayah bagi para siswa dengan cara berusaha untuk dekat dan akrab dengan siswa. Keempat, selalu melakukan kontrol. Kelima, melibatkan semua lapisan madrasah serta turut melibatkan masyarakat sekitar dalam mensukseskan visi dan misi madrasah.

Kata Kunci : Kepemimpinan Pendidikan, Pendidik, Tenaga Kependidikan.

\section{PENDAHULUAN}

Seperti sudah diketahui bersama bahwa pendidikan menurut UU SISDIKNAS No.20 tahun 2003 adalah usaha sadar dan terencana untuk mewujudkan suasana belajar dan proses pembelajaran agar peserta didik secara aktif mengembangkan potensi dirinya untuk 
memiliki kekuatan spiritual keagamaan, pengendalian diri, kepribadian, kecerdasan, akhlak mulia, serta keterampilan yang diperlukan dirinya dan masyarakat. Pendidikan dapat dilakukan melalui jalur formal, non formal maupun informal. Pada jalur formal, setidaknya ada dua bentuk pendidikan di Indonesia yaitu pendidikan berbentuk sekolah dan pendidikan berbentuk madrasah. Keduanya ini memiliki sejarah yang panjang dan telah ada sejak zaman penjajahan. Seiring berkembangnya zaman, banyak bermunculan sekolah sekolah Islam seperti Sekolah Islam Terpadu (SDIT). Begitu pula dengan madrasah, pelajaran yang diajarkan di madrasah tidak hanya mata pelajaran agama tapi juga mata pelajaran umum meskipun porsi mata pelajaran agama tetap lebih besar dibanding sekolah.

Madrasah memiliki sistem yang sama dengan sekolah umum. Dalam PMA No. 58 Tahun 2017 tentang Kepala Madrasah, dijelaskan bahwa kepala madrasah adalah pemimpin madrasah, yang memiliki kewenangan untuk melaksanakan tugas manajerial, mengembangkan kewirausahaan dan melakukan supervisi kepada guru dan tenaga

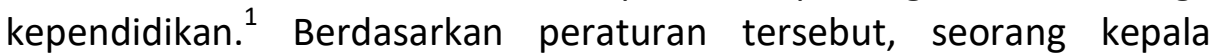
madrasah harus memiliki kompetensi leadership yang mumpuni sehingga dapat melaksanakan tugas manajerial dengan baik yang kemudian berdampak pada tercapainya tujuan madrasah.

Berdasarkan peran sentral kepala madrasah tersebut maka penelitian tentang kepemimpinan kepala madrasah dirasa penting. Adapun yang menjadi objek penelitian dalam penelitian ini adalah kepala madrasah Ibtidaiyah Al Huda yang bertempat di Karangnongko, kelurahan Maguwoharjo, kecamatan Depok, kabupaten Sleman, Yogyakarta. MI Al Huda berdiri pada tanggal 1 Januari 1970, beralamat di Karangnongko, Maguwoharjo, Depok, Sleman, Provinsi D.I Yogyakarta. MI Al Huda dipimpin oleh bapak Suharyanto, S.Pd, sebagai kepala madrasah. Visi dan misi dari MI Al Huda adalah "Terwujudnya Peserta Didik yang Beriman dan Bertaqwa, Cerdas, Terampil, Mandiri, Berakhlak Mulia, dan Berbudaya" Visi ini terjabarkan dalam tujuan yang ingin dicapai oleh madrasah yaitu Mewujudkan peserta didik

\footnotetext{
${ }^{1}$ PMA Republik Indonesia No. 58 Tahun 2017 tentang Kepala Madrasah
} 
yang memiliki keimanan dan ketaqwaan yang tinggi kepada Allah SWT, mencapai prestasi akademik dan non akademik yang tinggi, mewujudkan peserta didik yang memiliki ketrampilan yang tinggi, membentuk pribadi yang berakhlak mulia, mencetak generasi yang terampil dan mandiri serta mencetak generasi yang mengembangkan budaya dan peduli terhadap lingkungan. ${ }^{2}$

\section{METODE PENELITIAN}

Dilihat dari jenisnya, ini adalah jenis penelitian lapangan atau field research yaitu metode penelitian yang dilakukan di tempat atau lokasi di lapangan. ${ }^{3}$ Adapun metode pengumpulan data pada penelitian ini adalah metode dokumentasi yaitu cara pengumpulan informasi yang didapatkan dari dokumen, yakni peninggalan tertulis, arsip-arsip, akta ijazah, rapor, peraturan perundang-undangan, buku harian, surat-surat pribadi, catatan biografi, dan lain-lain yang memiliki keterkaitan dengan masalah yang diteliti. ${ }^{4}$ Selain itu penelitian ini juga menggunakan metode wawancara, yaitu teknik pengumpulan data yang dilakukan dengan cara bertanya langsung kepada responden atau informan. ${ }^{5}$

Lokasi atau tempat penelitian adalah MI Al Huda yang terletak di Karangnongko, Kelurahan Maguwoharjo, Kecamatan Depok, Kabupaten Sleman, Yogyakarta. Objek penelitian adalah Kepala Madrasah dan MI Al Huda. Objek penelitian ditentukan berdasarkan observasi singkat terhadap MI Al Huda dan kebijakan Kepala Madrasah dalam memimpin madrasah.

\section{LANDASAN TEORI}

Kepemimpinan atau leadership adalah kemampuan seseorang untuk mempengaruhi orang lain agar bekerja sama sesuai dengan rencana demi tercapainya tujuan yang telah ditetapkan. ${ }^{6}$ Dalam dunia

${ }^{2}$ Dokumentasi Profil MI Al Huda

3 Andi Prastowo, Metode Penelitian Kualitatif dalam Perspektif Rancangan Penelitian, (Yogyakarta: Ar Ruzz Media, 2014). Hal. 183.

${ }^{4}$ Ibid..., Hal. 226

5 Lembaga Penelitian, Dasar-Dasar Metodologi Penelitian, (Malang: IKIP Malang, 1997). Hal. 86

\footnotetext{
${ }^{6}$ Ibid ..., Hal 26
} 
pendidikan, kepemimpinan pendidikan adalah suatu kesiapan, kemampuan yang dimiliki oleh seseorang dalam proses mempengaruhi, mendorong, membimbing, mengarahkan dan menggerakkan orang lain yang ada hubungannya dengan pelaksanaan dan pengembangan pendidikan dan pengajaran, agar segenap kegiatan dapat berjalan secara efektif dan efisisen yang pada akhirnya dapat mencapai tujuan pendidikan nasional. ${ }^{7}$

Menurut Imam Muslimin, kepemimpinan adalah suatu proses dan perilaku untuk mempengaruhi aktifitas para anggota kelompok untuk mencapai tujuan bersama yang dirancang untuk memberikan manfaat individu dan organisasi. ${ }^{8}$ Kepemimpinan atau leadership adalah kemampuan seseorang untuk mempengaruhi orang lain agar bekerja sama sesuai dengann rencana demi tercapainya tujuan yang telah ditetapkan. ${ }^{9}$

Dalam Islam kepemimpinan merupakan kegiatan menuntun, membimbing, memadu dan menunjukkan jalan yang diridhai Allah SWT. Kegiatan ini bermaksud untuk menumbuh kembangkan kemampuannya sendiri di lingkungan orang-orang yang dipimpin dalam usahanya untuk mencapai ridha Allah selama kehidupannya di akhirat kelak. $^{10}$ Berdasarkan pengertian-pengertian diatas, dapat disimpulkan bahwa kepemimpinan adalah sebuah proses saling mempengaruhi antar kelompok yang di dalamnya terdapat orang yang mempengaruhi atau biasa disebut pemimpin, dan orang yang di pengaruhi atau anggota. Proses saling mempengaruhi ini dilakukan dalam suatu wadah atau organisasi yang memiliki tujuan yang sama, sehingga menuntut suatu kerjasama antar kelompok.

Pemimpin dalam bahasa Arab adalah khalifah, yang berarti penguasa. Khalifah adalah seorang penguasa yang berkewajiban memelihara, mengatur dan mendaya gunakan kemampuannya.

7 Burhanuddin, Analisis Administrasi Manajemen dan Kepemimpinan Pendidikan,, (Jakarta: Bumi Aksara, 1994). Hal. 65

8 Imam Muslimin, Pemimpin Perubahan, Model Kepemimpinan dalam Transisi Perubahan Kelembagaan. (Malang: UIN Maliki Press, 2013). Hal. 27

${ }^{9}$ Ibid..., Hal 26

${ }^{10}$ Ibid..., Hal. 323 
Kemampuan tersebut menunjukkan rasa syukur manusia atas karunia Allah. ${ }^{11}$ Sedangkan dalam bahasa Inggris disebut dengan leader. Sedangkan kepemimpinan disebut dengan leadership. Leadership adalah people who do the right thing-seseorang yang melakukan sesuatu secara tepat. ${ }^{12}$ Pemimpin adalah seseorang yang memiliki kemampuan khusus untuk mengajak, mendorong dan mempengaruhi orang-orang yang dipimpinnya. Pemimpin identik dengan orang yang memiliki kekuasaan dan kewenangan dalam mengambil suatu keputusan atau kebijakan. Oleh karena itu, seorang pemimpin dituntut untuk memiliki kecakapan-kecakapan tertentu untuk menunjang tugas yang diembannya.

Dalam dunia pendidikan dikenal suatu istilah kepemimpinan pendidikan. Kepemimpinan pendidikan adalah suatu kesiapan, kemampuan yang dimiliki oleh seseorang dalam proses mempengaruhi, mendorong, membimbing, mengarahkan dan menggerakkan orang lain yang ada hubungannya dengan pelaksanaan dan pengembangan pendidikan dan pengajaran, agar segenap kegiatan dapat berjalan secara efektif dan efisien, yang pada akhirnya mencapai tujuan pendidikan dan pengajaran yang telah ditetapkan. ${ }^{13}$ Dalam konteks pendidikan, kepemimpinan pendidikan kepala sekolah adalah pemimpin sekolah yang memiliki tugas, tanggung jawab dan wewenang dalam membuat suatu kebijakan untuk sekolah. Pemimpin pendidikan memiliki pengaruh dan peran yang penting terhadap pendidikan Islam di Indonesia. Pemimpin yang memiliki visi yang kuat akan mampu mengoptimalkan seluruh warga sekolah di masingmasing bagiannya.

Berdasarkan PMA No. 58 Tahun 2017 Kepala madrasah bertanggung jawab dalam a) menyusun rencana kerja jangka menengah untuk masa empat tahun, b) menyusun rencana kerja tahunan, c) mengembangkan kurikulum, d) menetapkan pembagian

${ }^{11}$ Hadari nawawi, Kepemimpinan Menurut Islam, (Yogyakarta: Gadjah Mada University Press, 1993) Hal. 323.

12 Imam Muslimin, Pemimpin Perubahan..., Hal. 23

13 Burhanuddin, Analisis Administrasi Manajemen dan Kepemimpinan Pendidikan,, (Jakarta: Bumi Aksara, 1994). Hal. 65 
tugas dan pendayagunaan guru dan tenaga kependidikan, e) menandatangani ijazah, surat keterangan hasil ujian akhir, surat keterangan pengganti ijazah,dan dokumen akademik lain, f) mengembangkan nilai kewirausahaan, serta g) melakukan penilaian kinerja guru dan tenaga kependidikan. Pemimipin yang ideal adalah pemimpin yang mampu menjalankan fungsi dan perannya mengatur dan mengendalikan jalannya organisasi dalam hal ini adalah organisasi sekolah/madrasah. ${ }^{14}$

Untuk dapat melaksanakan tugas-tugas kepemimpinan tersebut, kepala sekolah harus memiliki beberapa kompetensi yang menunjang tugas kepemimpinanya. Kompetensi-kompetensi tersebut ialah kompetensi kepribadian, manajerial, kewirausahaan, supervisi dan sosial. berbicara mengenai kepemimpinan berarti akan membahas juga mengenai tipologi kepemimpinan dan juga gaya kepemimpinan yang sangat mempengaruhi cara pemimpin dalam berhubungan dan bekerja sama dengan bawahan atau anggotanya.

Tipologi kepemimpinan adalah studi mengenai bagaimana cara seorang pemimpin menggunakan kekuasannya. ${ }^{15}$ Cara memimpin seorang pemimpin terbagi dalam beberapa tipe, tiga diantaranya adalah (1) Tipe Otoriter, yaitu pemimpin bertindak sebagai diktator terhadap anggota kelompoknya. Pemimpin jenis ini memiliki wewenang untuk memberikan penghargaan atau menghukum. Pemimpin yang bertipe demikian dipandang sebagai orang yang memberikan perintah dan mengharapkan pelaksanaannya secara dogmatis dan selalu positif. ${ }^{16}$ (2) Tipe Laizes Faire yaitu pemimpin memberikan kebebasan yang seluas-luasnya kepada setiap anggota. Pemimpin sama sekali tidak terlibat dalam kegiatan dan semua pekerjaan dilimpahkan kepada bawahannya sehingga pemimpin tidak memiliki wibawa, tidak memiliki koordinasi dengan bawahan dan tidak bertanggung jawab. (3) Kepemimpinan demokratis, tipe ini disebut juga dengan kepemimpinan modernis dan partisipatif. Semua anggota

${ }^{14}$ Drs Beni Ahmad Saebani. M.Si \& Lin Sumantri,M.Ag. KEPEMIMPINAN. (Bandung: Pustaka Setia, 2014.Hal. 23

${ }^{15}$ Burhanuddin, Analisis Administrasi..., Hal. 99

${ }^{16}$ Ibid ..., Hal. 99 
diajak berpartisipasi menyumbangkan pikiran dan tenaganya untuk mencapai tujuan organisasi. ${ }^{17}$

Ada banyak faktor yang mendukung berhasilnya seorang pemimpin dalam melaksanakan tugas kepemimpinan. Selain karena faktor internal, tentunya karena ada faktor eksternal. Faktor internal adalah faktor-faktor dari dalam diri pemimpin tersebut, dalam hal ini adalah watak atau bawaan. Sedangkan faktor eksternal adalah faktor dari luar diri pemimpin. Seperti motivasi dan juga anggota kelompok yang mendukung berjalannya suatu kepemimpinan. Adapun beberapa kondisi atau kemampuan seorang kepala madrasah yang menjadikan suksesnya kepemimpanan kepala sekolah, di antaranya yaitu:

1. Kepala Sekolah Sebagai Pejabat Formal

Di dalam lingkungan organisasi, kepemimpinan terjadi melalui dua bentuk, yaitu kepemimpinan formal dan kepemimpinan informal. Kepemimpinan formal terjadi apabila di lingkungan organisasi jabatan otoritas formal dalam organisasi tersebut diisi oleh orang-orang yang ditunjuk atau dipilih melalui proses seleksi. Sedang kepemimpinan informal terjadi, di mana kedudukan pemimpin dalam suatu organisasi diisi oleh orangorang yang muncul dan berpengaruh oleh orang lain karena kecakapan khusus atau berbagai sumber yang dimilikinya dirasakan mampu memecahkan persoalan organisasi serta memenuhi kebutuhan dari anggota organisasi yang bersangkutan. ${ }^{18}$

Oleh karena itu, kepala sekolah pada hakikatnya adalah seorang pejabat formal, karena pengangkatannya melalui proses dan prosedur yang berlaku.

2. Kepala Sekolah Sebagai Manajer

Manajemen menurut Harold Koontz seperti yang dikutip oleh Burhanuddin adalah usaha pencapaian tujuan yang diinginkan dengan membangun suatu lingkungan (suasana) yang favorable terhadap pekerjaan yang dilakukan oleh orang-orang dalam

${ }^{17}$ Drs Beni Ahmad Saebani.M.Si \& Lin Sumantri, M.Ag. KEPEMIMPINAN. Hal. 127

${ }^{18}$ Ibid..., Hal. 84 
kelompok terorganisir. ${ }^{19}$ Seorang kepala sekolah harus bisa menjadi seorang manajer dalam bidang pendidikan yaitu sebagai perencana, organisator, pemimpin dan seorang pengendali. Keberadaan manajer pada suatu organisasi sangat diperlukan, sebab organisasi sebagai alat untuk mencapai tujuan, dalam hal ini tujuan pendidikan nasional. ${ }^{20}$

3. Kepala Sekolah Sebagai Seorang Pemimpin

Esensi dari kepemimpinan adalah kepengikutan (followership), kemauan orang lain atau bawahan untuk mengikuti keinginan pemimpin, itulah yang menyebabkan pemimpin menjadi pemimpin.dengan kata lain pemimpin tidak akan terbentuk apabila tidak ada bawahan. Kepala sekolah sebagai pemimpin dituntut untuk selalu bertanggunng jawab dan memelihara keseimbangan antara guru, staff, dan siswa di satu pihak, dan kepentingan sekolah serta kepentingan masyarakat dipihak lain. Sehingga tercipta suasana keseimbangan, keserasian antara kehidupan sosial dan masyarakat. Selain itu, kepala sekolah juga harus dapat memberikan bimbingan, mengadakan koordinasi kegiatan, mengadakan pengendalian atau pengawasan dan mengadakan pembinaan. $^{21}$

4. Kepala Sekolah Sebagai Pendidik

Kepala sekolah sebagai pendidik mencakup dua hal pokok, yaitu sasaran atau kepada siapa perilaku tersebut diarahkan dan bagaimana peranan sebagai pendidi tersebut dilaksanakan. Sasaran atau objek yang akan dipengaruhi adalah peserta didik, guru dan tenaga administratif. Adapun caranya dilakukan dengan langkah keteladanan dan pendekatan persuasi atau pendekatan langsung. $^{22}$

5. Kepala Sekolah Sebagai Staff

Salah satu peran kepala sekolah adalah sebagai seorang pejabat formal atau sebagai pemimpin formal. Sebagai seorang pejabat, kepala sekolah juga memiliki tanggung jawab kepada

\footnotetext{
${ }^{19}$ Burhanuddin, Analisis Administrasi..., Hal.15

${ }^{20}$ Wahjosumidjo, Kepemimpinan Kepala Sekolah..., Hal. 96

${ }^{21}$ Ibid..., Hal. 119

${ }^{22}$ Ibid..., Hal. 125
} 
atasan. Tugas-tugas sebagai staff kepala sekolah hanya dapat berhasil efektif apabila setiap kepala sekolah menyadari dan memahami perannya sebagai staff, serta mampui mewujudkan dala perilaku dan perbuatan. ${ }^{23}$

\section{PEMBAHASAN}

Kepemimpinan merupakan salah satu faktor yang sangat penting dalam suatu organisasi karena sebagian besar keberhasilan dan kegagalan suatu organisasi ditentukan oleh kepemimpinan seorang pemimpin dalam organisasi tersebut. Atau dengan kata lain dapat dikatakan bahwa Pemimpinlah yang dapat mempengaruhi dan mengarahkan kemana organisasi yang ia pimpin tersebut dibawa. Terkait dengan kepemimpinan di bidang pendidikan, khususnya kepemimpinan pendidikan Islam pada jenjang Madrasah Ibtidaiyah, maka peneliti telah melakukan penelitian di Madrasah Ibtidaiyah Al Huda Karangnongko, Maguwoharjo, Depok, Sleman, Yogyakarta. Kami membagi kategori kepemimpinan Kepala Madrasah dalam 5 bidang yaitu Kepemimpinan Kepala Madrasah secara umum, kepemimpinan Kepala Madrasah pada tenaga pendidik dan tenaga kependidikan, kepemimpinan Kepala Madrasah pada siswa, kepemimpinan Kepala Madrasah dalam bidang Keuangan, serta kepemimpinan Kepala Madrasah dalam menjalin hubungan dengan masyarakat.

1. Kepala Sekolah Sebagai Pejabat Formal

Kepala MI Al Huda, Bapak Suharyanto, ditugaskan di MI Al Huda selama satu periode setelah sebelumnya sempat menjabat sebagai kepala sekolah di jenjang madrasah Tsanawiyah. Awal mula beliau menjadi PNS adalah dengan mendaftar pada seleksi pegawai negeri sipil yang diadakan oleh pemerintah. Kemudian, Pak Suharyanto mendaftar sebagai kepala sekolah dengan melalui berbagai tahapan seleksi kepala sekolah. Sebagai pejabat formal, Bapak Suharyanto tentunya memiliki wewenang untuk memimpin madrasah sesuai dengan PMA No. 58 Tahun 2017 tentang Kepala Madrasah.

${ }^{23}$ Ibid..., Hal. 131 
Tugas-tugas kepala sekolah terbagi menjadi tiga bagian, yakni tugas harian, bulanan dan tahunan. Demi terlaksananya tugastugas tersebut, kepala sekolah selalu berada di madrasah untuk memantau seluruh kegiatan madrasah.

2. Kepala Sekolah Sebagai Manajer

Kepala madrasah memiliki andil besar dalam memimpin dan membina tenaga pendidikan dan kependidikan. Kepala madrasah MI Al Huda, memberikan kebebasan penuh kepada pendidik untuk melakukan inovasi dalam pembelajaran, dengan pertimbangan bahwa pendidik lebih memahami kondisi siswa di masing-masing kelas. Akan tetapi, kebebasan yang diberikan tersebut harus sesuai dengan peraturan yang berlaku, seperti harus melengkapi administrasi pembelajaran. ${ }^{24}$ Memberikan kewenangan langsung kepada guru mampu meningkatkan rasa tanggung jawab guru terhadap tugasnya. Pemberian tanggung jawab penuh kepada guru dapat meningkatkan tingkat kreatifitas guru dalam mengajar, yang berdampak pada kepercayaan masyarakat kepada madrasah karena memiliki guru-guru yang profesional.

Adapun untuk tenaga kependidikan, Kepala madrasah memiliki wewenang penuh dalam memilih pembantu di bidang kurikulum, kesiswaan, keuangan, sarana prasarana. Pemilihan calon pembantu kepala dibidang-bidang tersebut diserahkan langsung kepada Kepala madrasah, yayasan memberikan wewenang penuh kepada Kepala madrasah untuk memilih personil-personil tenaga kependidikan. Tenaga kependidikan yang lain yang juga membantu bidang kependidikan madrasah adalah tenaga kebersihan, tenaga perpustakaan dan tenaga kemanan. Semua tenaga kependidikan tersebut dipilih langsung oleh kepala madrasah dengan mempertimbangkan kemampuan dan latar belakang dari masing-masing personal.

Kepala madrasah juga melakukan evaluasi kepada setiap pendidik dan tenaga kependidikan untuk meningkatkan mutu sekolah. Evaluasi pendidik dilakukan secara berkala tiap 6 bulan sekali dengan melakukan cek administrasi pembelajaran. Sedangkan untuk tenaga kependidikan dilakukan musyawarah

${ }^{24}$ Wawancara dengan Bapak Suharyanto, Kepala Madrasah Ibtidaiyah Al Huda 
bersama mengenai hambatan-hambatan yang terjadi dalam melaksanakan tugas.

Evaluasi dalam kepemimpinan memiliki posisi penting dalam kepemimpinan. Evaluasi merupakan salah satu cara untuk menentukan strategi dan garis besar haluan madrasah di tahun mendatang. Tanpa adanya evaluasi, madrasah hanya akan berjalan di tempat tanpa adanya inovasi-inovasi yang baru. Evaluasi kepala madrasah di Ml Al Huda juga dilakukan secara rutin bersama dengan komite madrasah.

3. Kepala Sekolah Sebagai Seorang Pemimpin

Secara umum, Bapak Suharyanto selaku Kepala Madrasah Ibtidaiyah Al Huda dalam setiap keputusan yang beliau ambil terkait kebijakan dalam madrasah selalu melibatkan musyawarah dengan pihak lain. Beliau selalu mengadakan rapat singkat untuk mengambil keputusan terkait kebijakan dalam Madrasah. Meskipun bersifat insidental dan mendesak, beliau selalu berusaha untuk melakukan musyawarah dahulu dengan guru-guru maupun pegawai di MI Al Huda meskipun tidak seluruhnya.

Namun demikian, bukan berarti Kepala Madrasah tidak memiliki ketegasan dan hanya menerima keputusan Musyawarah. Kepala Madrasah menampung usulan dan masukan dari Guru dan Karyawan namun juga tetap memperhatikan peraturan dari Madrasah. Jika usulan dan masukan guru dan karyawan tidak sejalan dengan peraturan Madrasah, maka Kepala Madrasah dapat mempertimbangkan dan memutuskan yang terbaik.

Dalam hubungannya dengan guru dan pegawai MI Al Huda, beliau juga berusaha untuk tidak terlalu membuat sekat, sehingga beliau berharap dengan tidak adanya sekat yang terlalu jauh antara Kepala Madrasah dan guru maupun pegawai akan membuat hubungan yang erat dan dekat seperti keluarga sehingga akan memunculkan rasa saling keterbukaan serta memudahkan pula Kepala Madrasah dalam memonitor kinerja para guru dan pegawai. ${ }^{25}$

Peserta didik merupakan salah satu unsur penting yang ada dalam pendidikan yang memiliki hak dan kewajiban dalam

${ }^{25}$ Wawancara dengan Bapak Suharyanto, Kepala Madrasah Ibtidaiyah Al Huda 
madrasah. Adapun kewajiban peserta didik beberapa diantaranya adalah belajar dengan rajin dan mengikuti peraturan sekolah yang telah dibuat oleh sekolah. Sedangkan hak peserta didik beberapa diantaranya adalah mendapatkan ilmu pengetahuan, mengembangkan bakat yang dimiliki oleh siswa, dan kenyamanan di lingkungan sekolah.

Untuk mewujudkan hal tersebut, Kepala madrasah memberikan perhatian penuh kepada peserta didik dibantu dengan semua pendidik dan tenaga kependidikan di MI Al Huda. Salah satu usaha yang dilakukan oleh sekolah untuk mengembangkan bakat siswa adalah memberikan ekstrakurikuler. Ekstrakurikuler di MI Al Huda diadakan dengan harapan dapat mengembangkan bakat siswa dan memberikan skill yang nantinya dapat dikembangkan di jenjang selanjutnya. Ada beberapa kegiatan ekstra kurikuler yang diadakan di MI Al Huda misalnya pencak silat, pramuka, seni hadrah, qiraah, dan sebagainya. ${ }^{26}$

Kepala madrasah memiliki 2 staff pembantu di bidang keuangan, yaitu bapak Sugito dan ibu Wiwi. Pengelolaan keuangan madrasah seperti pencatatan pemasukan dan pengeluaran harian maupun bulanan, penyusunan laporan keuangan dilakukan oleh dua staff tersebut dengan kontrol dari kepala madrasah. ${ }^{27}$

Kebijakan kepala madrasah di bidang keuangan adalah memberikan wewenang penuh kepada staff keuangan untuk mengatur keuangan madrasah, namun tetap dalam pengawasan kepala madrasah. Sumber pendapatan utama MI Al Huda adalah dari bantuan pemerintah. Kendala utama dalam pengelolaan keuangan madrasah adalah jika ada keterlambatan pencairan dana BOS oleh pemerintah, sehingga menggangu kestabilan keuangaan dan biaya operasional madrasah.

4. Kepala Sekolah Sebagai Pendidik

Kepala sekolah dalam memimpin selalu memberikan teladan kepada seluruh warga madrasah di MI Al Huda. Salah satunya adalah dengan disiplin berangkat dan pulang sesuai dengan
${ }^{26}$ Ibid
${ }^{27}$ Ibid 
waktunya. Kepala sekolah juga selalu memberikan contoh kepada siswanya untuk gemar belajar, yaitu dengan memberikan nasihat kepada siswa dalam berbagai kesempatan.

Kepala sekolah juga selalu mengingatkan guru untuk selalu menggunakan metode yang sesuai dengan karakter dan kondisi siswa, hal ini merupakan salah satu bentuk perhatian kepala sekolah untuk mengembangkan potensi belajar peserta didik.

5. Kepala Sekolah Sebagai Staff

Sebagai madrasah yang berdiri di tengah perkampungan warga tentu tak dapat lepas dengan interaksi dengan warga sekitar, termasuk di dalamnya juga interaksi dengan wali siswa. Bapak Suharyanto selaku Kepala Madrasah senantiasa berusaha untuk membina hubungan yang baik dengan wali siswa dan juga warga sekitar. Salah satu buktinya adalah keterlibatan wali siswa dalam penyusunan visi madrasah. Dalam menyusun visi, terlebih dahulu madrasah membuat konsep lalu kemudian ditawarkan pada wali siswa. Menurut Bapak Suharyanto, pada awalnya konsep visi madrasah adalah "Terwujudnya Peserta Didik yang Beriman dan Bertaqwa, Cerdas, Terampil, Mandiri, dan Berakhlak Mulia" namun kemudian mendapat ususlan dari wali siswa untuk menambahkan kata "berbudaya" karena MI Al Huda terletak di Yogyakarta. ${ }^{28}$ Selain itu upaya mendekatkan madrasah dengan masyarakat adalah dengan diadakannya Pengajian Rutin setiap akhir bulan yang bertempat di MI Al Huda dimana panitia pengajiannya sendiri berasal dari wali siswa.

Dari pembahasan tersebut dapat disimpulkan bahwa kepala MI Al Huda, Bapak Suharyanto telah melakukan tugas kepemimpinan sesuai dengan tugas pokok dan fungsi sebagai seorang kepala madrasah. Karena telah memiliki pengalaman dalam kepemimpinan, Kepala Madrasah tidak menemukan kesusahan atau kendala yang berarti. Faktor internal yang menonjol merupakan salah satu hal yang mempengaruhi cara Kepala MI Al Huda dalam melaksanakam tugas kepemimpinan di madrasah. Tipe kepemimpinan beliau adalah tipe demokratis yang tercermin dalam cara beliau membuat kebijakan dan

${ }^{28}$ Wawancara dengan Bapak Suharyanto, Kepala Madrasah Ibtidaiyah Al Huda 
mengambil keputusan yang selalu mendahulukan musyawarah dan berasaskan pemikiran yang modern sesuai dengan keadaan aktual yang terjadi.

Hambatan atau masalah yang dihadapi adalah beberapa guru kurang menguasai IT. Sehingga dalam penulisan raport siswa terutama untuk kelas yang menggunakan kurikulum 2013 mengalami sedikit hambatan. Selain itu terdapat pula beberapa guru yang belum linier, misalnya guru lulusan PAI menjadi guru kelas, atau ada juga lulusan Bahasa Inggris yang menjadi guru kelas.

Gaya kepemimpinan demokratis memiliki pengaruh yang signifikan terhadap kinerja pendidik dan tenaga kependidikan. Dengan memberikan kebebasan untuk mengembangkan kreatifitas dalam mengajar, menyelesaikan masalah dengan musyawarah, mendampingi setiap kegiatan yang berlangsung di sekolah, memberikn arahan dan evaluasi kepada semua pendidik dan tenaga kependidikan serta keterbukaan kepala madrasah dalam menerima kritik dan saran merupakan beberapa indikator gaya kependidikan demokratis yang berhasil di implementasikan dalam kegiatan di madrasah.

Gaya kepemimpinan kepala madrasah mempengaruhi kinerja pendidik dan tenaga kependidikan di MI Al Huda, Maguwo, Sleman, DIY. Hasil dari gaya kepemimpinan demokratis tersebut adalah pendidik memiliki kepuasan terhadap kepemimpinan kepala madrasah karena diberikan ruang untuk berkreasi dalam pembelajaran serta tidak segan untuk menyampaikan permasalahan yang sedang di hadapi, dan juga merasa nyaman untuk meminta saran serta pendapat dari kepala madrasah. Dampak dari ini adalah guru memiliki daya kreasi tinggi sehingga mampu mencetak output sesuai dengan tujuan madrasah.

\section{KESIMPULAN}

Berdasarkan hasil wawancara dan juga analisis di atas ada beberapa hal yang dapat disimpulkan dari penelitian terhadap kepemimpinan Pendidikan Islam di Madrasah Ibtidaiyah, dalam hal ini adalah Kepala Madrasah Ibtidaiyah Al Huda, Karangnongko, 
Maguwoharjo, Depok, Sleman, Yogyakarta. Ada 5 bidang yang dikategorikan dalam menganalisis kepemimpinan Kepala MI Al Huda, yaitu Kepemimpinan kepala madrasah secara umum, kepemimpinan kepala madrasah pada tenaga pendidik dan tenaga kependidikan, kepemimpinan kepala madrasah pada siswa, kepemimpinan kepala madrasah dalam bidang keuangan, serta kepemimpinan kepala madrasah dalam menjalin hubungan dengan masyarakat. Gaya kepemimpinan kepala madrasah sangat mempengaruhi kinerja pendidik dan tenaga kependidikan. Hal tersebut dibuktikan dengan Pertama, secara umum kepemimpinan Kepala MI Al Huda adalah kepemimpinan dengan gaya kepemimpinan demokratis. Beliau selalu mengedepankan musyawarah dan memperhatikan pendapat bawahannya sebelum mengambil keputusan maupun kebijakan dalam Madrasah.

Kedua, kaitannya dengan kepemimpinan kepala Madrasah dengan Tenaga Pendidik dan Kependidikan, kepala madrasah memberikan kebebasan terhadap guru maupun karyawan untuk berkreasi dan berinovasi dalam melaksanakan tugasnya selama tidak bertentangan dengan aturan yang ada di MI Al Huda. Ketiga, kaitannya dengan kepemimpinan kepala madrasah dengan peserta didik atau siswa, beliau selalu berusaha menjadi figur ayah bagi para siswa dengan cara berusaha untuk dekat dan akrab dengan siswa. Beliau juga memperhatikan aspek keislaman siswa sehingga diadakanlah kebijakan tentang ekstra keagamaan seperti seni hadrah, qiraah, kaligrafi, dan sebagainya. Keempat, kaitannya dengan bidang keuangan Kepala Madrasah tetap melakukan kontrol meskipun sudah ada karyawan yang bertugas mengurus bagian keuangan. Kelima, kaitannya dengan kepemimpinan Kepala Madrasah dalam hubungan dengan masyarakat, beliau membuat kebijakan dengan mengadakan pengajian rutin akhir bulan dengan peserta dan panitia dari kalangan wali siswa sendiri.

\section{DAFTAR PUSTAKA}

Agustinus Hermino, 2014, Kepemimpinan Pendidikan di Era Globalisasi. Yogyakarta: Pustaka Pelajar. 
EVALUASI, 3(1), Maret 2019, ISSN 2580-3387 (print) |ISSN 2615-2886 (online) http://doi.org/10.32478/evaluasi.v3i1.201

Burhanuddin, 1994. Analisis Administrasi Manajemen dan Kepemimpinan Pendidikan, Jakarta: Bumi Aksara, Daryanto, 2011, Kepala Sekolah Sebagai Pemimpin Pembelajaran, Yogyakarta: Gava Media.

Imam Muslimin, 2013. Pemimpin Perubahan, Model Kepemimpinan dalam Transisi Perubahan Kelembagaan. Malang: UIN Maliki Press.

Lembaga Penelitian. 1997. Dasar-Dasar Metodologi Penelitian, Malang: IKIP Malang.

Maragustam, 2016. Filsafat Pendidikan Islam Menuju Pembentukan Karakter Menghadapi Arus Global, Yogyakarta: Kurnia Kalam Semesta.

Munawir, Imam, 2000. Asas-Asas Kepemimpinan dalam Islam. Surabaya: Usaha Nasional.

Nawawi, Hadari, 1993. Kepemimpinan Menurut Islam, Yogyakarta: Gadjah Mada University Press.

Prastowo, Andi. 2011. Memahami Metode-Metode Penelitian, Yogyakarta : Ar Ruzz Media.

Purwanto, Ngalim, 1987. Administrasi dan Supervisi Pendidikan. Bandung: CV Remadja Karya.

Saebani, Beni Ahmad \& Lin Sumantri, 2014. KEPEMIMPINAN. Bandung: Pustaka Setia.

Wahjosumidjo, 2005. Kepemimpinan Kepala Sekolah Tinjauan Teoritik dan Permasalahannya. Jakarta: PT Raja Grafindo Persada 